\title{
PCR-based identification of Mycobacterium murphy causing Canine Leproid Granuloma Syndrome in Niterói, southeast Brazil - case report
}

\author{
[Identificação baseada em PCR de Mycobacterium murphy causando Síndrome do Granuloma Lepróide Canino em \\ Niterói, sudeste do Brasil] - Relato de Caso

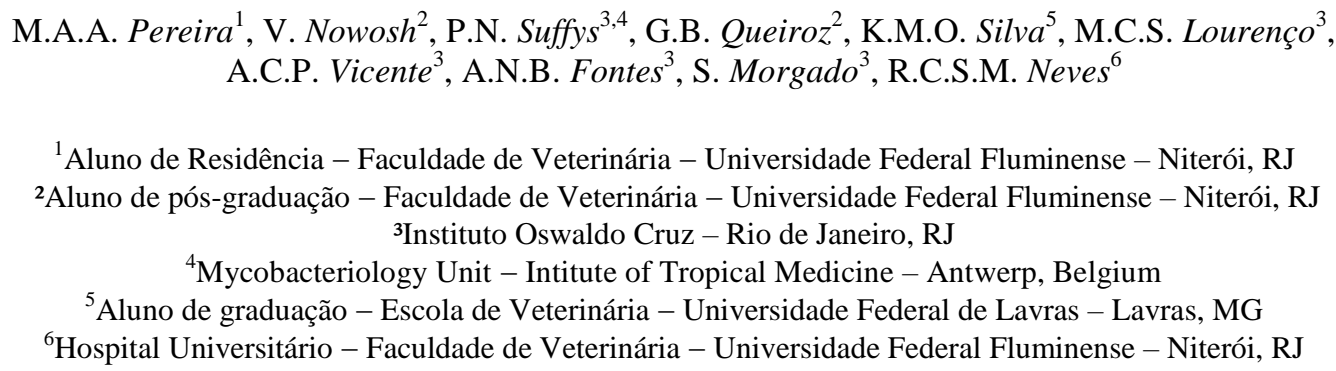

\begin{abstract}
Canine Leproid Granuloma Syndrome (CLGS), also known as canine leprosy, is a cutaneous nodular infectious disease caused by Mycobacterium sp.. Despite being reported worldwide, it is still quite unknown and underdiagnosed. Diagnosis may be achieved by cytopathology or histopathology of skin lesions, but identification of the infectious agent is complex, since bacterial in vitro growth is not possible, relying upon molecular techniques such as PCR to confirm Mycobacterium DNA in the sample. We report a CLGS case in Niteroi, Rio de Janeiro state, Brazil, diagnosed by cytopathology and submitted to molecular identification of the agent. PCR amplification of $h s p 65$ gene was performed and revealed $100 \%$ genetic homology to M. murphy strain. This is the first CLGS report with molecular identification in Rio de Janeiro state, and this finding should raise awareness about CLGS as a differential diagnosis among granulomatous skin diseases in this region.
\end{abstract}

Keywords: CLGS, hsp65 sequence, isolate Metcalfe, molecular methods

\section{RESUMO}

A síndrome de granuloma leproide canino (SGLC), também conhecida como lepra canina, é uma doença infecciosa cutânea nodular causada por Mycobacterium sp. Apesar de ser relatada mundialmente, ainda é bastante desconhecida e subdiagnosticada. O diagnóstico pode ser conseguido por citopatologia ou histopatologia de lesões cutâneas, mas a identificação do agente infeccioso é complexa, uma vez que o crescimento in vitro bacteriano não é possível, dependendo de técnicas moleculares como a PCR para confirmar o DNA de Mycobacterium na amostra. Relatou-se um caso da SGLC em Niterói, estado do Rio de Janeiro, Brasil, diagnosticado por citopatologia e submetido à identificação molecular do agente. Foi realizada amplificação por PCR do gene hsp65, que revelou 100\% de homologia genética com a cepa M. murphy. Este é o primeiro relato da SGLC com identificação molecular no estado do Rio de Janeiro, o que mostra a importância de se acrescentar a SGLC ao diagnóstico diferencial das doenças granulomatosas de pele nessa região.

Palavras-chave: CLGS, sequência hsp65, isolado Metcalfe, métodos moleculares

\section{INTRODUCTION}

Canine Leproid Granuloma Syndrome (CLGS) is a cutaneous disease caused by Mycobacterium infection. It presents itself as single or multiple nodules commonly appearing on the dorsal ear fold (Malik et al., 2006; Malik et al., 2013). Cytological and histologic examination reveal medium-sized negative stained bacilli with

Recebido em 26 de maio de 2017

Aceito em 6 de setembro de 2017

E-mail: marcoaurelio1987@hotmail.com 
Romanowski-type stains that are positive in acid-fast stains such as Ziehl-Nielsen (Twomey et al., 2005). In vitro growth requirements for these bacteria have not been determined due to its fastidious growth, but negative culture is useful for excluding other clinically relevant Mycobacteria (Malik et al., 2006). Since isolation is still not possible, molecular diagnosis based on the $500 \mathrm{bp}$ of the $16 \mathrm{~S}$ rRNA gene (Hughes et al., 2000) or the ITS1 region (Fyfe et $a l ., 2008)$ are useful for its etiological diagnosis, also giving information about genetic correlation with isolated Mycobacterium species (Hughes et $a l ., 2000)$. CLGS may be underdiagnosed, since its etiological identification is difficult and other granulomatous diseases are reported in dogs (Santoro et al., 2008; Malik et al., 2013). There are few reports in Brazil and even fewer using molecular characterization. This report focuses on a confirmed case of CLGS with molecular identification of species in the city of Niteroi, Rio de Janeiro, Brazil.

\section{CASE REPORT}

A 3-year-old mixed-breed female dog was admitted at Hospital Universitário de Medicina Veterinária Professor Firmino Mársico Filho, Universidade Federal Fluminense, with a tumor on the right ear fold (Figure 1). The nodule measured $3,0 \times 2,5 \times 1,5 \mathrm{~cm}$. Fine Needle Citology (FNC) was obtained and stained in Giemsa, revealing pyogranulomatous inflammation, with negative stained bacilli inside macrophages (Figure 2A). Mycobacterium was suspected and a new sample by FNC was stained in acid-fast stain, revealing positive stained bacilli inside and outside macrophages (Figure 2B). Excisional biopsy was performed, and samples were submitted to histopathology, culturing, and molecular analysis (Figure 3). Histopathology revealed pyogranulomatous inflammation with extensive necrosis. Bacterial growth in MGIT-960 and in Löwestein-Jensen medium were negative. Molecular analysis results were as follows. The patient was treated with systemic and topical antibiotic therapy and did not present any signs involving the disease after healing the wound. Genotyping analyses were performed at Laboratório de Biologia Molecular Aplicada a Micobactérias and at Laboratório de Genética Molecular de Microorganismos, Instituto Oswaldo Cruz in Rio de Janeiro city, Brazil. Samples were submitted to DNA extraction and purification using the Qiagen kit DNeasy Blood \& Tissue (Invitrogen do Brasil). Summarily, 180 $\mu$ l of ATL buffer and $20 \mu 1$ of proteinase $\mathrm{K}$ from the kit were added to the biopsy, mixed by vortex and after overnight incubation at $56^{\circ} \mathrm{C}$, DNA was purified using spin-column from the kit as described by the manufacturer. Amplification of part of hsp65 was performed using the primer sets Tb11 (F ACC AAC GAT GGT GTG TCC AT) and Tb12 (R CTT GTC GAA CCG CAT ACC CT) and using amplification conditions as described in earlier studies (Devulder et al., 2005; Fyfe et al., 2008), yielding a fragment of $441 \mathrm{bp}$. The PCR product was analyzed on agarose gel, purified with the Illustra PCR and Gel Band Purification Kit (GE Healthcare, Little Chalfont, BUX, UK) and submitted to sequencing using the same primers, using the ABI Big Dye 3.1 Terminator Ready Reaction Kit (Applied Biosystems do Brasil). Sequences were generated on an ABI 3730 Genetic Analyzer (Applied Biosystems) and compared with sequences available on NCBI. Our sequence was $100 \%$ identical to that of EF611178.1, derived from Mycobacterium sp. strain CLGS, isolate Metcalfe.

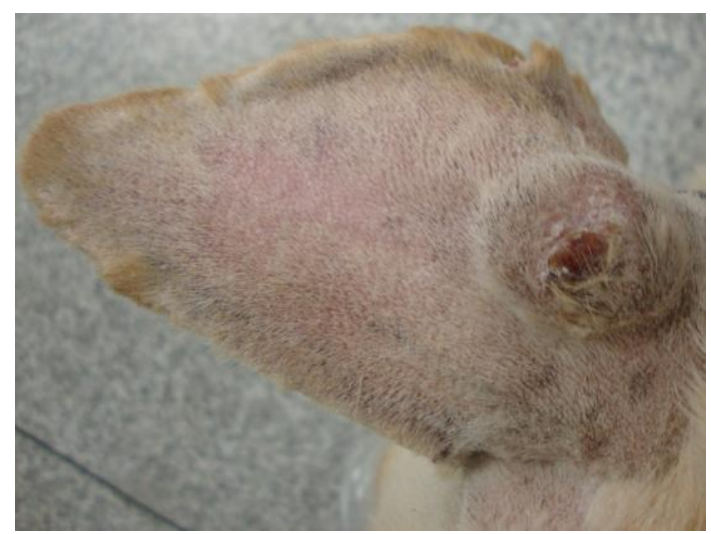

Figure 1. Dog presenting a granuloma on right ear fold; The nodule measured $3.0 \times 25 \times 1.5 \mathrm{~cm}$. Niterói, 2014. 


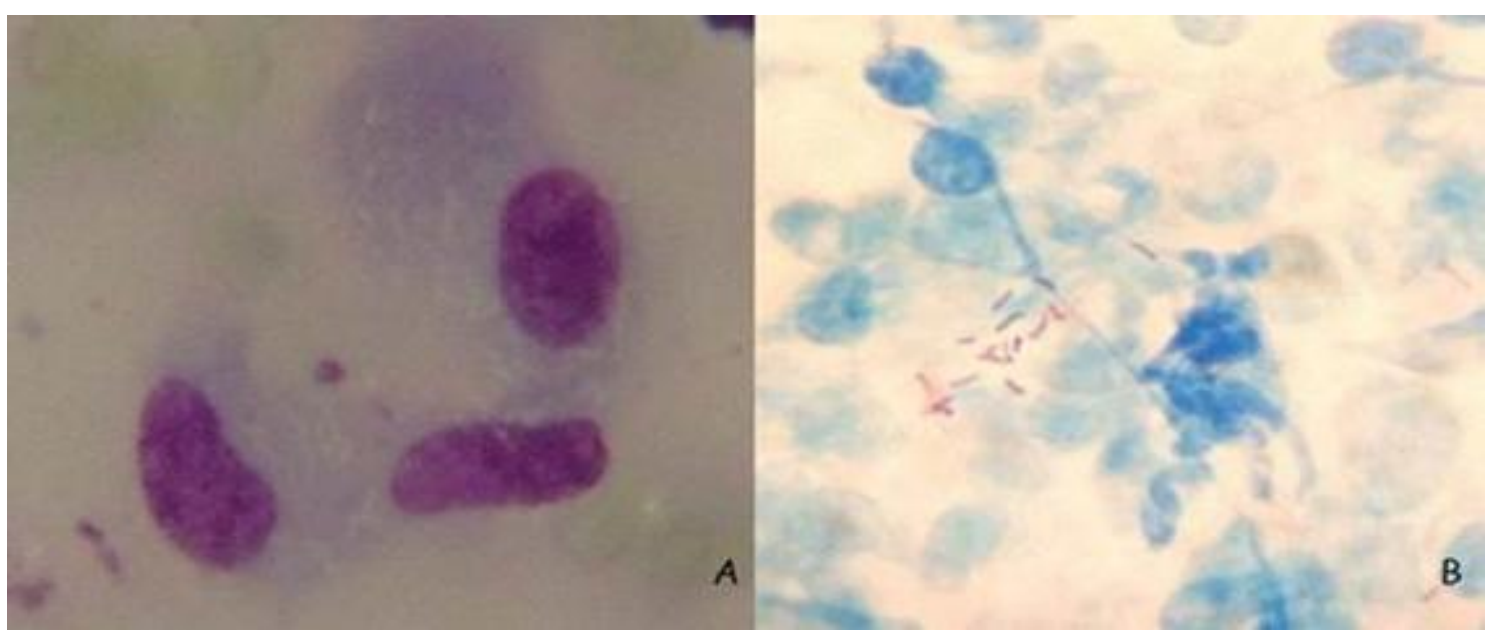

Figure 2. Fine needle cytology slides from canine granuloma sample. A. Macrophages presenting negative stained bacilli in its cytoplasm. Pyogranulomatous inflammation wa diagnosed. Giemsa stain, 1000x. B. Acid-fast staining shows positive stained bacilli outside macrophages. Acid-fast stain, 1000x. Niterói, 2014.

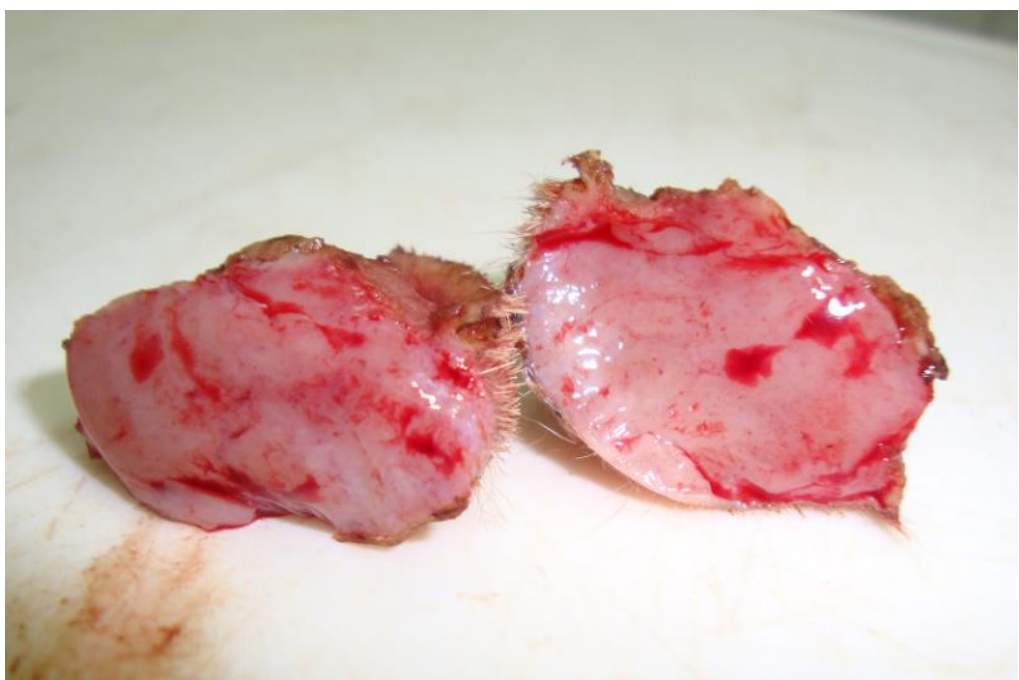

Figure 3. Tissue specimen of granuloma obtained by excisional biopsy. Specimens were then submitted to histopathology, culturing and molecular analysis. Niterói, 2014.

\section{DISCUSSION}

There have been reports of Leprosy-like Mycobacterium species in several animal hosts, but mycobacterial infections are considered uncommon in dogs (Malik et al., 2006). First description of CLGS was from Zimbabwe, in a boxer and a bullmastiff (Smith, 1973), with reports from Australia appearing soon afterwards. Our report shows similarities with other Brazilian and worldwide reports, such as the patient presenting a single tumor in the ear pinna with no further systemic compromise (Maruyama, 2010; Conceição et al., 2011;
Tabanez e Arrais, 2013). Mostly, such species are difficult to grow in vitro and therefore need molecular confirmation on the DNA level. About 15 years ago, the Mycobacterium species was described in several dogs from Australia and $16 \mathrm{~S}$ rDNA reference sequence was determined (Hughes et al., 2000). In a later study, part of the hsp65 sequence of the isolate Mycobacterium sp. strain CLGS, isolate Metcalfe (also called $M$. murphy) specific for this organism was reported (Fyfe et al., 2008). In this report, PCR result was positive for $M$. murphy. This isolate presents high nucleotide homology to pathogenic species M. simiae, $M$. interjectum, and $M$. genavense 
(Hughes et al., 2000) but since its requirements for in vitro growth are not known, it remains as a not fully described species. Sequence analysis of the $16 \mathrm{~S}$ rDNA is used for identification to the species level, and concatenated analysis of $16 \mathrm{~S}$ rDNA and hsp65 sequences allowed phylogenetic classification of this species, being very close to $M$. simiae and the cat isolate $M$. $s p$ tarwin (Fyfe et al., 2008). Because we use sequencing of part of $h s p 65$ as the routine procedure in our laboratory for identification of Mycobacterium to the species level, we applied this system for the identification of the acid-fast bacilli and $100 \%$ homology was observed with the hsp65 sequence of $M$. murphy. Few reports exist on the occurrence of canine leprosy in Brazil and even less on molecular confirmation of the identity of the causative agent. A review of histopathological records and direct PCR sequence analysis on samples from 38 dogs with CLGS between 2000 and 2008 was described, confirming the presence of $M$. murphy in $13 \mathrm{dogs}$ from the states of São Paulo and Minas Gerais (Conceição et al., 2011). We now extend these observations on a possibly emerging infectious disease to another state of Southeast Brazil.

\section{CONCLUSION}

CLGS, even though being common in Australia, is still quite unknown worldwide and in Brazil. This could be due to its benign presentation, with few symptoms and sometimes a self-limited course of disease. Since negative-stained bacilli in routine cytology and histopathology stains can be hard to find and in vitro growth requirements for these bacteria have not yet been established, molecular diagnosis is extremely useful for CLGS diagnosis. This report raises questions about CLGS's role as a possible emerging infectious disease in Rio de Janeiro state, since it is the first case of CLGS identified by molecular analysis as $M$. murphy in the municipal district of Niteroi. Since it is believed that CLGS is underdiagnosed, veterinary physicians should be aware of it as a differential diagnosis among other common nodular cutaneous diseases, such as neoplastic, inflammatory, and infectious conditions.

\section{REFERENCES}

CONCEIÇÃO, L.G.; ACHA, L.M.; BORGES, A.S. et al. Epidemiology, clinical signs, histopathology and molecular characterization of canine leproid granuloma: a retrospective study of cases from Brazil. Vet. Dermatol., v.22, p.249-256, 2011.

DEVULDER, G.; PEROUSE DE MONTCLOS, M.; FLANDROIS, J.P. A multigene approach to phylogenetic analysis using the genus Mycobacterium as a model. Int. J. Syst. Evol. Microbiol., v.55, p.293302, 2005.

FYFE, J.A.; MCCOWAN, C.; O'BRIEN, C.R. et al. Molecular characterization of a novel fastidious Mycobacterium causing lepromatous lesions of the skin, subcutis, cornea, and conjunctiva of cats living in Victoria, Australia. J. Clin. Microbiol., v.46, p.618626, 2008.

HUGHES, M.S.; JAMES, G.; BALL, N. et al. Identification by $16 \mathrm{~S}$ rRNA gene analysis of a potential novel Mycobacterial species as an etiological agent of canine leproid granuloma syndrome. J. Clin. Microbiol., v.38, p.953-959, 2000.

MALIK, R.; HUGHES, M.S.; MARTIN, P.; WIGNEY, D. Canine Leproid Granuloma Syndrome (Canine Leprosy). In: GREENE, C.E. Infectious diseases of the dog and cat. Saint Louis: Saunders, 2006. p.480-482.

MALIK, R.; SMITS, B.; REPPAS, G. et al. Ulcerated and nonulcerated nontuberculous cutaneous mycobacterial granulomas in cats and dogs. Vet. Dermatol., v.24, p.146-153, 2013.

MARUYAMA, S. Estudo clínico-epidemiológico de casos de Granuloma lepróide canino, diagnosticados pelas histopatologia e técnica de reação em cadeia de polimerase (PCR). 2010. 95f. Dissertação (Mestrado em Clínica Veterinária) - Faculdade de Medicina Veterinária e Zootecnia, Universidade de São Paulo, São Paulo, SP.

SANTORO, D.; PRISCO, M.; CIARAMELLA, P. Cutaneous sterile granulomas / pyogranulomas, leishmaniasis and mycobacterial infections. J. S. Anim. Pract., v.49, p.552-561, 2008.

SMITH, R.I.E. Canine skin tuberculosis. Rhod. Vet. J., v.3, p.63-64, 1973.

TABANEZ, P.C.R.; ARRAIS, P. Granuloma lepróide canino em Brasília. Acta Vet. Bras., v.7, Supl.1, p.183184, 2013.

TWOMEY, L.N.; WUERZ, J.A.; ALLEMAN, E.R.A. A "down under" lesion on the muzzle of a dog. Vet. Clin. Pathol., v.34, p.161-163, 2005. 